\title{
CORRECTION OF DISORDERS IN THE SYSTEM OF HEMOSTASIS AT MISCARRIAGE IN THE I-ST TRIMESTER OF PREGNANCY
}

\section{КОРЕКЦІЯ ПОРУШЕНЬ В СИСТЕМІ ГЕМОСТАЗУ ПРИ НЕВИНОШУВАННІ В I ТРИМЕСТРI ВАГІТНОСТI}

Резюме. Аналіз ефективності терапії невиношування вагітності з використанням дуфастону та флогензиму показав, що їх застосування сприяє нормалізації показників системи гемостазу, зниженню кількості акушерських та перинатальних ускладнень.

Ключові слова: невиношування вагітності, гемостаз, дуфастон, флогензим.

The problem of miscarriage of pregnancy remains topical one despite the progress achieved in the treatment and prevention of complications of pregnancy. The frequency of of this pathology is quite high and there is no tendency to decrease. It constitutes $10-20 \%$ of all pregnancies and $55 \%$ - after 3 miscarriages of pregnancy (miscarriage accustomed). Percentage of miscarriages increases significantly after interruption of previous pregnancies. Thus, after the 1st spontaneous abortion it is $23 \%$, after 2 miscarriages $-29 \%$, after 3 miscarriages - up to $55 \%$ [1].

Purpose of the research. Evaluating the effectiveness of the proposed treatment of the miscarriage in the I-st trimester of pregnancy of the primary and secondary hemostasis, fibrinolytic activity of blood, markers of DIC-syndrome.

Material and methods. We have analyzed the effectiveness of the proposed treatment in 46 women with threatened miscarriage in the first trimester (the main group). The control group consisted of 50 women with miscarriage in the first trimester who took generally accepted complex therapy. The groups were statistically similar. State of platelet-vascular hemostasis stage was estimeted by adhesive platelet percentage (APP), as well as by spontaneous platelet aggregation index (SPAI). Total coagulative potential of blood plasma (recalcification time (RT), thrombin time (TT), prothrombin time (PT) and activated partial thromboplastin time (APTT)), fibrinolytic activity of plasma, potential activity of plasminogen, antiplasmins, fibrinogen level (FGL), activity of antithrombin III (AT-III), concentration of soluble fibrin monomer complexes (SFMC) in blood and early fibrinogen degradation products (EFDP) in urine and urokinatic urine activity (UUA) were determined according to the instructions to sets of reagents produced by the Scientific Industrial Company

\section{"SIMKO-Ltd", Lviv.}

Discussion of the results. The data of our previous studies of the system of hemostasis in women with miscarriage in the first trimester pointed to significant changes in the first place of the primary hemostasis, that caused a rise in the general blood coagulative potential against the background of some decrease of fibrinolytic activity and activity of anticoagulative system and also of normal indices of proteolytic system [2-4].

In connection with the abnormalities discovered in the system of hemostasis in women with miscarriage of pregnancy it became necessary to add medications that affect the aggregation blood state to the complex of therapeutic remedies [5, 6]. We have chosen Enzyme preparation phlogenzym, which is a specifically selected combination of two complementary enzymes (Bromelain $90 \mathrm{mg}$, $48 \mathrm{mg}$ Trypsinum) with Rutinum of plant origin (Rutoside $100 \mathrm{mg}$ ). The drug significantly improves microcirculation. It is able to reduce thrombosis and intensify processes of fibrinolysis; it inhibits platelet aggregation, produces an effect on adhesive molecules and increases the ability of erythrocytes to change their shape [6].

Correction of treatment to pregnant women with chronic form of DIC-synrome against the background of threatened abortion was performed as follows:

1. Duphaston - in case of threatened abortion was administered only once $40 \mathrm{mg}$, then $10 \mathrm{mg}$ every 8 hours until disappear of threatening symptoms.

2. Chophytol - the drug potentiates the action of antiplatelet agents, it was administered as indicated in Table 23 times a day before meals for 2-3 weeks.

3. Phlohenzym - 2 tablets 30-60 minutes befoe meals, with plenty of fluid (up to $200 \mathrm{~mL}$ ) three times a day for 10-14 days with transition to maintenance therapy: 1 tablet three times a day for 1 month.

All pregnant women tolerated the proposed (C) Yasnikovska S.M., Petriyk B.V., 2016 
treatment well, none of them had unpleasant subjective sensations. All pregnancies in the main group were preserved, in the control group -3 pregnancies were interrupted up to 12 weeks.

The course of the proposed therapy resulted in normalization of hemostatic indices. Studying the total hemocoagulative potential after treatment, we observed extension of its principal temporal characteristics and increased activity of anticoagulative system (table 1).

Thus, the extension of RT to 28.3 seconds compared with a group of women who were conventionally treated $(\mathrm{p}<0.05)$ was indicative of retardation of an internal way of coagulation. Reliable growth of PT 1.3 times $(p<0.05)$ testified to the presence of a weak trend towards inhibition of external way of blood clotting. We also registered a decrease in activity of fibrinogenesis, that manifested itself in lengthening TT 1.56 times $(p<0.05)$. A growth of APTT 1.5 times proved once again the fact of inhibition of hemocoagulative potential, especially as it was in conditions of increased activity of AT-III ( $\mathrm{p}<0.05)$.

Under the influence of combined therapy with phlogenzym positive changes have taken place in the system of platelet-vascular hemostasis, the indices of which (SPAI - Spontaneous Platelet Aggregation Index and PAP - Platelet Adhesion Percentage) decreased respectively 2.1 and 2.65 times relatively to the comparison group $(\mathrm{p}<0.05)$. Taking into consideration that activation of this phase of hemostasis, ac cording to our research, caused the development of chronic subclinical forms of DIC-syndrome in pregnant women with miscarriage in the first trimester, the use of the proposed therapeutic complex by this contingent of women will enable them to reduce the risk of complications mentioned above. Especially as we have registered a reliable decrease in blood concentrations of markers of DIC-syndrome (table 2). It was confirmed by the decline of SFMC 4.5 times $(\mathrm{p}<0.05)$; FDP in urine 9.7 times $(\mathrm{p}<0.05)$ and growth of Luki-Lorand factor activity by $12.89 \%$ $(p<0.001)$. Changes of indices of fibrinolytic system

Table 1

Changes of the total coagulative potential in pregnant women with threatening miscarriage who took the proposed complex of treatment $(x \pm S x)$

\begin{tabular}{|l|c|c|}
\hline \multicolumn{1}{|c|}{ Indices studied } & $\begin{array}{c}\text { Pregnant women } \\
\text { who took the proposed } \\
\text { course of treatment } \\
\mathrm{n}=46\end{array}$ & $\begin{array}{c}\text { Pregnant women with miscarriage } \\
\text { who took the conventional treat- } \\
\text { ment } \\
\mathrm{n}=50\end{array}$ \\
\hline Recalcification time, sec & $\begin{array}{c}118.3 \pm 3.71 \\
\mathrm{p}<0.001\end{array}$ & $90.01 \pm 4.06$ \\
\hline Prothrombin time, sec & $\begin{array}{c}23.40 \pm 1.27 \\
\mathrm{p}<0.05\end{array}$ & $18.10 \pm 1.64$ \\
\hline $\begin{array}{l}\text { Thrombin time, } \\
\text { sec }\end{array}$ & $\begin{array}{c}19.20 \pm 1.52 \\
\mathrm{p}<0.05\end{array}$ \\
\hline $\begin{array}{l}\text { Activated Partial Throm- } \\
\text { boplastin Time, sec }\end{array}$ & $\begin{array}{c}47.3 \pm 2.72 \\
\mathrm{p}<0.001\end{array}$ & $29.95 \pm 1.62$ \\
\hline Antithrombin III, \% & $93.62 \pm 2.06$ & $85.93 \pm 2.91$ \\
\hline
\end{tabular}

Note: $p$ - the degree of reliability of differences of indices in pregnant women with miscarriage who took the proposed course of treatment and women with generally accepted treatment

Table 2

Changes of indices in the state of intra-vascular hemocoagulation in women with miscarriage of pregnancy who took the proposed complex of treatment $(\mathrm{x} \pm \mathrm{Sx})$

\begin{tabular}{|l|c|c|}
\hline \multicolumn{1}{|c|}{ Indices studied } & $\begin{array}{c}\text { Pregnant women who took the } \\
\text { proposed course of treatment } \\
\mathrm{n}=46\end{array}$ & $\begin{array}{c}\text { Pregnant women with miscarriage } \\
\text { who took the conventional treatment } \\
\mathrm{n}=50\end{array}$ \\
\hline $\begin{array}{l}\text { Concentration of SFMC (Solu- } \\
\text { ble Fibrin-Monomer Com- } \\
\text { plexes) in blood plasma, mkg/ml }\end{array}$ & $\begin{array}{c}8.07 \pm 1.62 \\
\mathrm{p}<0.001\end{array}$ \\
\hline $\begin{array}{l}\text { Concentration of FDP (Fibrin } \\
\text { Degradation Product) in urine, }\end{array}$ & $0.83 \pm 0.21$ \\
mkg/ml & $\mathrm{p}<0.001$ & $7.46 \pm 1.05$ \\
\hline XIII factor Activity, \% & $68.31 \pm 3.81$ & $55.42 \pm 3.63$ \\
& $\mathrm{p}<0.05$ & \\
\hline
\end{tabular}

Note: $p$ - the degree of reliability of differences of indices in pregnant women with miscarriage who took the proposed course of treatment and women with generally accepted treatment 
indicate to the improving of the rheological properties of blood in women after the proposed treatment (table 3).

Increase of urokinatic synthesis in JAA (juxtaglomelular apparatus) of kidneys led to the activation of Hageman-dependent mechanisms of fibrinolysis, which increased in comparison with the control group 1.4 times $(p<0.05)$. Indices NEFA and EFA, which testify to the presence of parabasal violations with lability of mast cells and denudation of vessels of microvascular flow, though not significantly increased, but did not reach the level of reliability $(\mathrm{p}>0.05)$.

Thus, we can conclude that the proposed complex of therapeutic measures leads to the arrest of chronic DIC-syndrom in women with miscarriage.

The analysis of further course of gestational period, labor and the postpartum period showed that the proposed therapeutic complex had led to a decrease in the frequency of obstetric complications. Percentage of preeclampsia decreased 2.3 times $(\mathrm{p}<0.05)$, threatened abortions in later stages -2.2 times $(\mathrm{p}<0.05)$. The state of fetus has significantly improved, that was evidenced by reducing of percentage HDF (Hageman Dependent Fibrinolysis) and FGR (Fetus Growth Retardation) - respectively 2.2 and almost 3 times $(\mathrm{p}<0.05)$.

The total number of abnormal labors in the main group has also reduced. Index of premature rupture of fetus membranes was less almost by $22.2 \%$ than indices in the comparison group $(\mathrm{p}<0.05)$.

Anomalies of labor activity (mainly primary and secondary weakness) and premature separation of normally located placenta were observed respectively 3.2 and 4.9 times less than in women in childbirth who took the conventional treatment $(\mathrm{p}<0.05)$. The latters often manifested pathology of the postpartum period that was associated with an abnormality of attachment of afterbirth $(16.42 \pm 4.53 \%$ to $4.55 \pm 2.57 \%, \mathrm{p}<0.05)$, that required manual separation of placenta and its removal and manual examination of the uterus. The increased volume of blood loss ( $0.8 \%$ of body weight) was 4 times more observed in women in childbirth of the comparison group. $13(19.40 \pm 4.83 \%)$ women in the same group brought child in the world by cesarean section; only $3(4.48 \pm 2.53 \%)$ of them - in a planned term. In the main group the frequency of operative delivery was $6.06 \pm 2.94 \%(\mathrm{p}<0.05)$.

The course of the postpartum period was also more favourable in women in childbirth, who took the proposed correction of hemostasis in small terms. They rarely manifested subinvolution of uterus (respectively $3.03 \pm 2.11 \%$ and $14.93 \pm 4.35 \%, \mathrm{p}<0.05$ ). No woman was diagnosed with development of endometritis, while in the comparison group it occurred in $2(2.99 \pm 2.08 \%)$ women surveyed. Parting of sutures on perineum $(\mathrm{p}<0.05)$ was registered three times less and infiltrative mastitis developed in one case

Table 3

Changes of indices of fibrinolytic system of blood in women with miscarriage who took the proposed course of treatment $(x \pm S x)$

\begin{tabular}{|l|c|c|}
\hline \multicolumn{1}{|c|}{ Indices studied } & $\begin{array}{c}\text { Pregnant women with miscar- } \\
\text { riage who took the proposed } \\
\text { course of treatment } \\
\mathrm{n}=46\end{array}$ & $\begin{array}{c}\text { Pregnant women with miscar- } \\
\text { riage who took the conventional } \\
\text { treatment } \\
\mathrm{n}=50\end{array}$ \\
\hline $\begin{array}{l}\text { TFA, } \\
\text { E440/ml/hour Total Fibrino- } \\
\text { lytic Activity }\end{array}$ & $17.54 \pm 1.75$ & $13.32 \pm 1.92$ \\
\hline $\begin{array}{l}\text { NEFA, } \\
\text { E440/ml/hour Non-enzy- } \\
\text { matic Fibrinolytic Activity }\end{array}$ & $5.78 \pm 0.72$ & $4.41 \pm 0.82$ \\
\hline $\begin{array}{l}\text { EFA, } \\
\text { E440/ml/hour (Enzymatic Fi- } \\
\text { brinolytic Activity) }\end{array}$ & $11.76 \pm 1.08$ & $8.91 \pm 1.12$ \\
\hline $\begin{array}{l}\text { Concentration of fibrinogen } \\
\text { in blood plasma, g/l }\end{array}$ & $3.20 \pm 0.21$ & $3.16 \pm 0.29$ \\
\hline $\begin{array}{l}\text { UUA, } \\
\text { Unit Urokinatic Urine Activ- } \\
\text { ity }\end{array}$ & $35.87 \pm 1.24$ & $32.29 \pm 1.57$ \\
\hline $\begin{array}{l}\text { Potential activity of Plasmin- } \\
\text { ogen, min }\end{array}$ & $19.86 \pm 1.35$ & $19.64 \pm 1.63$ \\
\hline $\begin{array}{l}\text { Hageman-dependent Fibri- } \\
\text { nolysis, min }\end{array}$ & $29.82 \pm 1.07$ \\
\hline
\end{tabular}

Note: $p$ - the degree of reliability of differences of indices in pregnant women with miscarriage who took the proposed course of treatment and women with generally accepted treatment 
$(1.52 \pm 1.50 \%)$ against four $(5.97 \pm 2.89 \%, \mathrm{p}>0.05)$.

Observations of women who were a part of the clinical groups further showed that 30 (45.46 \pm $6.13 \%$ ) examined women of the main group retained lactation up to 6 months. Women of the comparison group only in $17(25.37 \pm 5.32 \%)$ cases retained lactation to $4-6$ months and only $6(8.96 \pm 3.49 \%)$ women retained it after 6 months $(\mathrm{p}<0.05)$.

After the administered therapy we observed improvement in the state of newborns and their physical development. Weight of babies in the main group almost did not differ from weight of babies in the control group. In the group of women who took the corrective therapy, the state of newborns was estimated as "satisfactory" in $74.24 \pm 5.38 \%$ of cases, signs of asphyxia were found in $25.75 \pm 5.38 \%$. Children born with severe asphyxia were not recorded. The exam- ined women who took the conventional treatment had $53.73 \pm 6.09 \%$ of children born with asphyxia, born with severe asphyxia $-2.99 \pm 2.08 \%$ of cases $(p<0.05)$.There was no perinatal mortality of the women surveyed.

Conclusion. Thus, analyzing the results of the research, we can conclude that our proposed therapy with duphaston and phlogenzym promotes normalization of hemostatic system and reduction of the number of obstetric and perinatal complications.

Perspective of further investigations. In-depth study of changes in the hemostatic system in women with miscarriage in the I-st trimester of pregnancy and correction of infringements will have practical significance for the development of complex treatments threats pregnancy and prevention of perinatal complications.

\section{References}

1. Некоторые аспекты этиологии и патогенеза эмбриональных потерь в I триместре гестации / Ю.Э. Доброхотова, Р.И. Озерова, Ж.А. Мандрыкина, Л.С. Сора // Рос. вестн. акушера-гинеколога. - 2008. № 5. - С. 15-18. 2. Кравченко О.В. Особливості гемостазу у вагітних міста та сільської місцевості за умов децидуально-трофобластичних порущень / О.В. Кравченко, С.М. Ясніковська // Актуальні проблеми акушерства і гінекології, клінічної імунології та медичної генетики. - Вип. 15. - К.-Луганськ, 2008. - C. 102-104. 3. Ясніковська С.М. Попередження розвитку плацентарної дисфункиії у жінок з невиношуванням вагітності / С.М. Ясніковська // Materialy X mezinarodni vedecko-prakticka conference "Dny vedy-2014". - Dil25. Lekarstvi.: Praha. Publishing House "Education and Science" s.r.o. - P. 7-9. 4. Ясніковська С.М. Характеристика системи гемостазу у вагітних з анеміями / С.М. Ясніковська // Materialy XI mezinarodni vedecko-prakticka konference "Veda a technologie: krok do budoucnosti - 2015". - Dil 14. Lekarstvi. Biologicke vedy. Telovychova a sport.: Praha. Publishing House "Education and Science" s.r.o. - Р. 3-6. 5. Маркін Л.Б. Диферениійований підхід до корекиії гемодинамічних порушень у системі мати-плачента-плід при синдромі фетоплачентарної недостатності / Л.Б. Маркін, К.Л. Шатилович // ПАГ. - 2006. - № 1(413). - С. 67-72. 6. Ясніковська С.М. Нові підходи до корекції змін в системі гемостазу, шо розвинулися на тлі невиношування вагітності / С.М. Ясніковська // Актуальні досягнення медичних наукових досліджень в Украйні та країнах ближнього зарубіжжя: 3б. тез наук. робіт учасників міжнар. наук.-практ. конф. (м. Київ, 3-4 жовтня 2014 року). - К., 2014. - С. 86-90.

\section{КОРРЕКЦИЯ НАРУШЕНИЙ В СИСТЕМЕ ГЕМОСТАЗА ПРИ НЕВЫНАШИВАНИИ В I ТРИМЕСТРЕ БЕРЕМЕННОСТИ}

Резюме. Анализ эффективности терапии невынашивания беременности с использованием дуфастона и флогензима показал, что их применение способствует нормализации показателей системы гемостаза, снижению акушерских и перинатальных осложнений.

Ключевые слова: невынашивание беременности, гемостаз, дуфастон, флогензим.
CORRECTION OF DISORDERS IN THE SYSTEM OF HEMOSTASIS IN CASE OF MISCARRIAGE IN THE I-ST TRIMESTER OF PREGNANCY

Abstract. Analysis of the effectiveness of therapy of miscarriage using duphaston and flogenzym showed that their use contributed to normalization of the hemostatic system and to decline a number of obstetric and perinatal complications.

Key words: miscarriage, hemostasis, duphaston, phlogenzym.

Higher State Educational Establishment of Ukraine "Bukovinian State Medical University" (Chernivtsi)

Надійшла $18.02 .2016 \mathrm{p}$. Рецензент - проф. Юзько О.М. (Чернівці) 